\title{
Pengaruh Kompetensi dan Motivasi terhadap Kinerja Anggota Reskrim Polres Blitar Kota dalam Pengamanan Pemilihan Gubernur Jawa Timur Tahun 2018
}

\author{
Novi Indah Earlyanti* \\ Perguruan Tinggi Ilmu Kepolisian \\ Jalan Tirtayasa Raya No.6, Kebayoran Baru, Kota Jakarta Selatan, Indonesia \\ earlyantinovember24@gmail.com \\ Dhany Ardiansyah \\ Polisi Resort Blitar Kota \\ Jl. Jenderal Sudirman No.17, Kota Blitar, Jawa Timur, Indonesia \\ dhanyardiansyah22@gmail.com
}

Diterima: 09-02-2021

Disetujui: $16-06-2021$

Dipublikasi: 30-06-2021

\begin{abstract}
ABSTRAK
Polres Blitar merupakan salah satu wilayah hukum yang berada di Provinsi Jawa Timur yang ikut melaksanakan pengamanan Pemilihan Gubernur tahun 2018. Pengamanan dilakukan dari segi manajerial sumber daya manusia, dengan meminimalisir potensi-potensi gangguan keamanan yang ada agar tidak berkembang menjadi gangguan nyata. Tujuan penelitian untuk menganalisis pengaruh kompetensi dan motivasi terhadap kinerja anggota Reskrim Polres Blitar Kota dalam pengamanan Pemilihan Gubernur Jawa Timur tahun 2018. Pendekatan penelitian secara kuantitatif dengan metode survei. Data diperoleh dari pengisian kuesioner sejumlah 56 butir oleh 73 responden yang dijadikan sampel. Dari hasil analisis diperoleh persamaan regresi adalah $\hat{Y}=15,028+0,250 \mathrm{X}_{1}+0,313 \mathrm{X}_{2}+\mathrm{e}$; disimpulkan variabel kompetensi senilai 0,250 dan motivasi senilai 0,313 dengan nilai signifikansi 0,005 dan 0,000 secara parsial mempengaruhi kinerja anggota. Secara simultan, variabel kompetensi dan motivasi mempengaruhi kinerja sebesar 34,4\%. Anggota dapat menghasilkan kinerja yang baik bila ada dukungan kompetensi diri dan motivasi yang dibentuk. Hal ini tidak terlepas dari peran pimpinan yang memberi kesempatan anggota untuk mengikuti pendidikan pelatihan, memberikan tanggungjawab, memelihara interaksi positif sehingga menimbulkan motivasi yang dapat memacu anggota menyelesaikan target kerja yang telah ditentukan untuk menghasilkan kinerja yang baik
\end{abstract}

Kata Kunci:

Kompetensi; Motivasi; Kinerja; Anggota Reskrim; Pengamanan.

\begin{abstract}
Blitar Police Station is one of the jurisdictions in East Java Province which has participated in securing the Governor's Election in 2018. Security is carried out in terms of managerial human resources, by minimizing the potential of existing security disturbances soas not to develop into real disturbances. The research objective was to analyze the effect of competence and motivation on the performance of members of the Blitar City Police Criminal Investigation Unit in securing the East Java Governor Election in 2018. Quantitative research approaches and survey methods. Data obtained from filling out questionnaires of 56 items by 73 respondents who were sampled. From the results of the analysis obtained a regression equation is $\hat{Y}=$ $15,028+0,250 X_{1}+0,313 X_{2}+e$; It was concluded that the competency variable was 0.250 and motivation was 0.313 with a significant value of 0.005 and 0,000 which partially affected the performance of members. Simultaneously, the variables of competence and motivation affect performance by $34.4 \%$. Members can produce good performance if there is support for self-competence and motivation that is formed. This is inseparable from the role of the leader who gives members the opportunity to take part in training education, gives responsibility, maintains positive interactions so as to generate motivation that can spur members to complete predetermined work targets to produce good performance
\end{abstract}

Keywords:

Competence; Motivation; Performance; Criminal Investigation Members; Security. 


\section{PENDAHULUAN}

Dalam kajian ilmu politik, sistem pemilihan umum adalah prasyarat penting dalam negara demokrasi yang memberikan hak pilih bagi warga negaranya (Asshidiqie, 2013). Sejak lahirnya otonomi daerah, seluruh kepala daerah dipilih langsung oleh rakyat yang diusung melalui partai politik. Provinsi Jawa Timur sebagai salah satu daerah yang melaksanakan pemilihan kepala daerah (pilkada) untuk Gubernur pada tahun 2018. Daerah ini memiliki sejarah kuat terkait budaya dan jumlah massa fanatik. Kontestan pilkada Jawa Timur 2018 terbagi menjadi dua sosok kandidat yang memiliki rekam jejak kompetisi panjang saat pilkada periode sebelumnya, yaitu Syaifullah Yusuf (Gus Ipul) dan Khofifah Indar Parawangsa. Kedua kontestan merupakan mantan pengurus Gerakan Pemuda Anshor dan Muslimat Nahdlatul Ulama (NU).

Rekam jejak kompetisi mereka melahirkan sengketa yang tergolong unik, pada tahun 2008 keberatan terhadap rekapitulasi hasil penghitungan suara, dan pada tahun 2013 sengketa pada tahap verifikasi pendaftaran calon Gubernur dan Wakil Gubernur Jawa Timur dan rekapitulasi hasil penghitungan suara (Nazriyah, 2013). Sengketa yang terjadi sering mendatangkan konflik sosial dan selalu berkaitan dengan ketegangan sosial di masyarkat Indonesia yang majemuk. Untuk mengatasi ketegangan sosial di masyarakat sering dihadapkan pada kondisi anggota keamanan yang terbatas, baik secara personal maupun kelembagaan (Nitibaskara, 2018).

Polres Blitar Kota sebagai pemelihara keamanan ketertiban masyarakat, penegak hukum, pelindung, pengayom dan pelayan masyarakat perlu melakukan pengelolaan sumber daya manusia yang ditinjau dari dimensi kompetensi, motivasi dan kinerja anggota reskrim Polres Blitar Kota. Kompetensi sangat penting dalam membangun kinerja, karena dapat mencerminkan mereka yang mempunyai kinerja tinggi dan berprestasi (Dharma, 2018). Kompetensi merupakan suatu keahlian, pengetahuan, pendidikan, dan kemampuan untuk menjalankan sesuatu secara efektif (Simamora, 2004). Dari hasil penelitian Sriwidodo dan Haryanto (2010) diungkapkan bahwa kompetensi merupakan salah satu faktor yang berpengaruh positif dan signifikan terhadap kinerja. Hal ini sejalan dengan hasil penelitian Anjani (2019) bahwa kompetensi memiliki pengaruh yang signifikan terhadap kinerja. Hal lain yang sering dihubungkan dengan kinerja adalah motivasi. Motivasi adalah keadaan dalam diri seseorang untuk melakukan kegiatan tertentu untuk mencapai suatu tujuan (Handoko, 2005). Apabila kegiatan yang dilakukan berinteraksi baik maka motivasi akan tinggi, dan akan menyebabkan kinerja seseorang meningkat.Pimpinan yang dapat memberikan motivasi positif akan dapat mempengaruhi kinerja anggota (Kreitner dan Kinicki dalam Wibowo, 2014). Kinerja menjadi perhatian penting bagi pimpinan, karena kinerja anggota akan berdampak pada kinerja organisasi. Dari hasil penelitian Amiati dan Supriyono (2012) bahwa motivasi berpengaruh positif terhadap kinerja. Sedangkan Erni dan Ardianti (2019) menyatakan bahwa indikator keinginan untuk dapat hidup merupakan indikator tertinggi dari motivasi, sedangkan indikator terendah adalah keinginan untuk berkuasa, dan motivasi berpengaruh secara positif dan signifikan terhadap kinerja. 
Berdasarkan latar belakang, maka dirumuskan permasalahan mengenai seberapa besar pengaruh kompetensi dan motivasi terhadap kinerja anggota reskrim Polres Blitar Kota dalam pengamanan pemilihan gubernur Jawa Timur tahun 2018. Tujuan dari penelitian ini untuk mengetahui pengaruh antara komponen-komponen dalam kompetensi dan motivasi untuk mencapai kinerja yang tinggi. Hasil dari penelitian ini diharapkan mampu menambah pengetahuan tentang model empiris kompetensi dan motivasi yang dimiliki anggota reskrim terhadap capaian kinerja yang diharapkan.

\section{Kompetensi}

Konsep dan teori dari penelitian ini mengungkapkan bahwa kompetensi adalah kemampuan individu untuk melaksanakan suatu pekerjaan secara benar dan memiliki keunggulan berdasarkan pengetahuan, keahlian dan sikap (Edison, Anwar \& Komariyah, 21017). Sedangkan Wibowo (2007) mengungkapkan bahwa kompetensi merupakan kemampuan untuk melakukan suatu pekerjaan yang dilandasi pada keterampilan dan pengetahuan yang didukung oleh sikap kerja yang dituntut oleh pekerjaan tersebut. Menurut Spancer (2003) beberapa faktor yang dapat mempengaruhi kompetensi seseorang: (1) keyakinan dan nilai-nilai, (2) ketrampilan, (3) karakteristik, (4) motivasi, (5) isu emosional, (6) kemampuan intelektual, (7) budaya organisasi.

\section{Motivasi}

Uno (2009) motivasi adalah kekuatan dalam diri individu dalam melakukan kegiatan untuk mencapai tujuan. Motivasi sebagai faktor pendorong seseorang untuk bekerja memenuhi kebutuhannya (Mar'at dalam Warsito 2008). Kebutuhan menurut McClelland dalam Dahniel dan Dharma (2016) membagi menjadi tiga kategori, yaitu: kebutuhan akan prestasi (need of achievement, n Ach), kebutuhan akan afiliasi (need of affiliation, $\mathrm{n}$ Aff) dan kebutuhan akan kekuasaan (need of power, $\mathrm{n}$ Pow). Dipertegas oleh Hunsaker (2002) dalam Usman (2013) yang menyatakan bahwa motivasi berhubungan erat dengan: kinerja (performance), kemampuan (ability), pelatihan (training), sumber daya (resources), bakat (aptitude), hasrat (desire), dan komitmen (commitment).

\section{Kinerja}

Mangkunegara (2013) kinerja adalah hasil kerja secara kualitas dan kuantitas seseorang dalam melaksanakan tugas sesuai dengan tanggungjawab yang diberikan. Kinerja adalah cara melakukan pekerjaan dan hasil yang diperoleh dari pekerjaan itu (Wibowo dalam Dahniel dan Dharma 2013). Sejalan dengan yang disampaikan Edison et.al., (2017) bahwa kinerja sebagai hasil dari suatu proses yang diukur pada suatu periode tertentu berdasarkan standar yang telah ditetapkan. Menurut Amstrong dan Baron dalam Wibowo (2017) salah satu faktor yang mempengaruhi kinerja adalah personal factors, yang ditunjukkan oleh tingkat keterampilan, kompetensi, motivasi, dan komitmen individu. Wibowo (2017) mengklasifikasikan kinerja meliputi produktivitas, kualitas, ketepatan waktu dalam melaksanakan prosedur, cycle time, pemanfaatan sumber daya, dan biaya.

Berdasarkan fenomena, konsep dan kerangka teori yang dibangun, maka hipotesis dari penelitian ini adalah untuk menjawab pertanyaan penelitian yang telah diajukan, meliputi: 
$\mathrm{Ha}_{1}$ : Terdapat pengaruh secara signifikan kompetensi terhadap kinerja

$\mathrm{Ha}_{2}$ : Terdapat pengaruh secara signifikan motivasi terhadap kinerja

$\mathrm{Ha}_{3}$ : Terdapat pengaruh kompetensi dan motivasi secara simultan terhadap kinerja

Dari gambar dibawah ini tercermin bahwa kompetensi dan motivasi sebagai variabel independen dan kinerja sebagai variabel dependen.

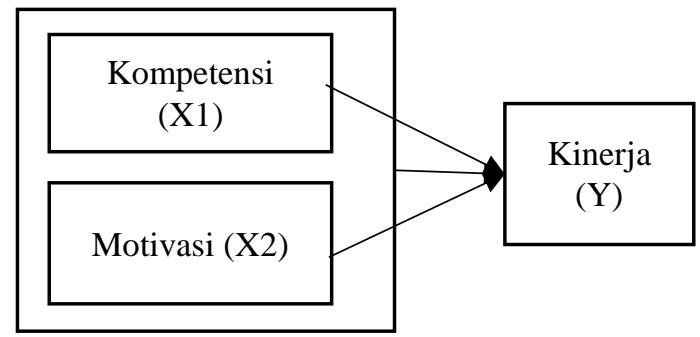

Gambar 1. Kerangka Konseptual

\section{METODE RISET}

Pendekatan penelitian yang digunakan kuantitatif dengan metode survei dan teknik pengumpulan data dengan instrumen penelitian yang sudah valid dan reliabel. Instrumen penelitian berupa kuesioner sebagai alat bantu untuk mengukur beberapa variabel yang akan diteliti (Neuman dalam Bambang 2011). Kuesioner penelitian disusun dan dikembangkan oleh peneliti berdasarkan turunan dari masing-masing variabel ke dalam indikator yang kemudian dikembangkan menjadi 56 butir pernyataan, terdiri dari 21 butir X1, 21 butir X2 dan 14 butir Y. Menggunakan alat ukur Skala Likert dengan rentang pilihan jawaban skala lima (1 s/d 5). Sugiyono (2015) menyatakan bahwa Skala Likert digunakan untuk mengukur sikap, pendapat, dan persepsi seseorang atau sekelompok orang tentang fenomena sosial.

Sebelum instrumen penelitian diberikan kepada 73 orang responden sebagai sampel yang terdiri dari 34 anggota Satreskrim Polres Blitar Kota dan 39 anggota Unit Reskrim Polsek jajaran Polres Blitar Kota, dilakukan uji instrumen untuk mengukur validitas dan reliabilitas. Ghozali (2005), pengukuran validitas dapat dilakukan dengan melihat nilai Correlated Item-Total Correlation dengan kriteria: jika nilai $r$ hitung lebih besar dari $r$ tabel dan nilainya positif, maka butir pertanyaan dikatakan valid. Hasil pengukuran nilai validitas terhadap 56 butir pernyataan variabel X1, X2 dan Y dinyatakan valid dengan nilai $\mathrm{r}$ hitung $>\mathrm{r}$ tabel $=0.3338$, yang telah diuji cobakan kepada 30 responden. Nunnally (dalam Ghozali, 2005) kuesioner dikatakan reliabel jika jawaban seseorang terhadap pertanyaan konsisten dari waktu ke waktu dan memberikan nilai Cronbach's Alpa lebih besar dari 0.444. Dari hasil perhitungan diperoleh nilai Cronbach's Alpha untuk X1 $=0,938$ untuk X2 $=0,938$ dan untuk $\mathrm{Y}=0,909$. Nilai tersebut menunjukkan bahwa kuesioner dikatakan reliabel karena lebih besar dari 0.444.

Analisis data meliputi uji syarat data dan uji hipotesis dengan menggunakan uji t, uji $\mathrm{F}$, koefisien determinasi, analisis regresi linier berganda. Semua tahapan proses analisis data dilakukan dengan menggunakan program SPSS (Statistic Package For Social Science) versi 21. 


\section{HASIL PENELITIAN DAN PEMBAHASAN}

\section{Hasil Penelitian}

Deskripsi data responden berjumlah 73 orang anggota reskrim Polres Blitar Kota, meliputi objek penelitian: usia responden, jenjang pangkat responden, pendidikan responden. Untuk persentase rentang usia responden terbesar pada penelitian ini berada diantara usia 31- 40 tahun sebanyak 38 responden.

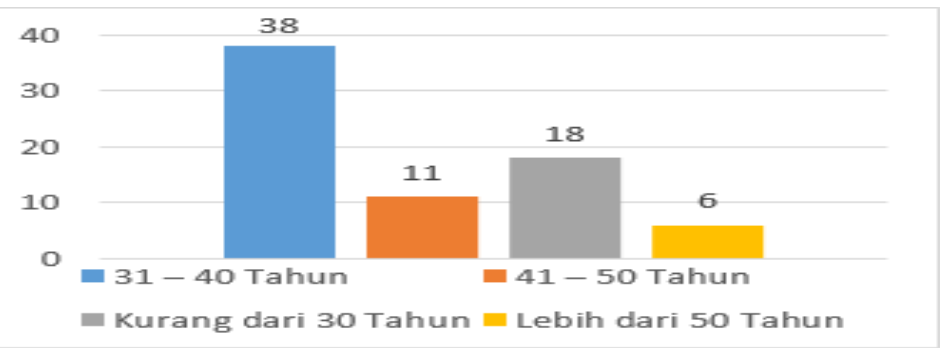

Gambar 2. Distribusi Frekuensi Usia Responden Sumber: Hasil olah data oleh peneliti

Data responden untuk jenjang kepangkatan, diperoleh prosentase terbesar berada pada jenjang pangkat brigadir polisi kepala (bripka) sebanyak 29 responden.

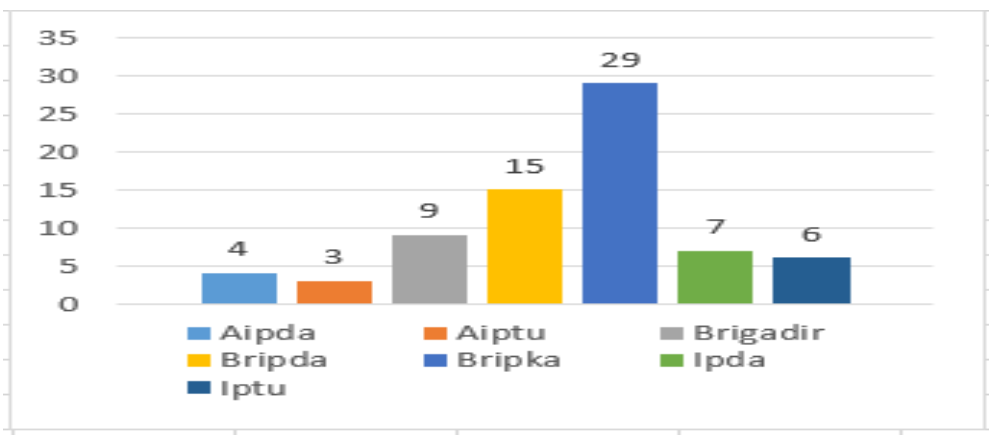

Gambar 3. Distribusi Frekuensi Pangkat Responden Sumber: Hasil olah data oleh peneliti

Untuk persentase tingkat pendidikan umum responden terbesar pada penelitian ini berada pada jenjang pendidikan Sekolah Menengah Atas (SMA), sebanyak 37 responden.

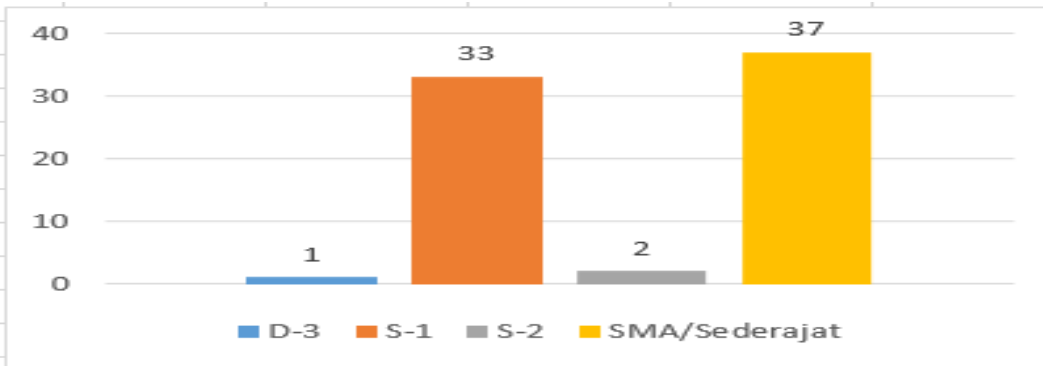

Gambar 4. Distribusi Frekuensi Pendidikan Umum Responden Sumber: Hasil olah data oleh peneliti

Untuk persentase tingkat pendidikan pengembangan responden terbesar pada penelitian ini berada pada jenjang pendidikan dan kejuruan/pendidikan pengembangan personil/pendidikan pelatihan/pelatihan/kursus sebanyak 42 responden. 


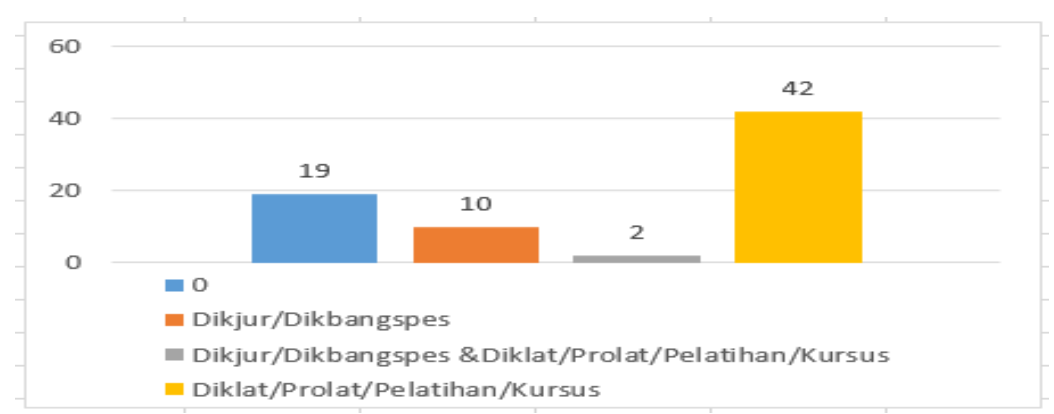

Gambar 5. Distribusi Frekuensi Pendidikan Pengembangan Responden Sumber: Hasil olah data oleh peneliti

Langkah selanjutnya adalah dengan melakukan uji asumsi, dimulai dengan melakukan uji normalitas dengan tujuan untuk melihat apakah nilai residual terdistribusi normal atau tidak (Ghozali, 2005). Persyaratan normalitas terpenuhi jika penyebaran titik-titik residual berada di sekitar garis normal, pada grafik normal plot dapat disimpulkan bahwa titik-titik menyebar dan penyebarannya di sekitar garis diagonal, sehingga grafik ini menunjukkan bahwa model regresi tidak menyalahi asumsi normalitas.

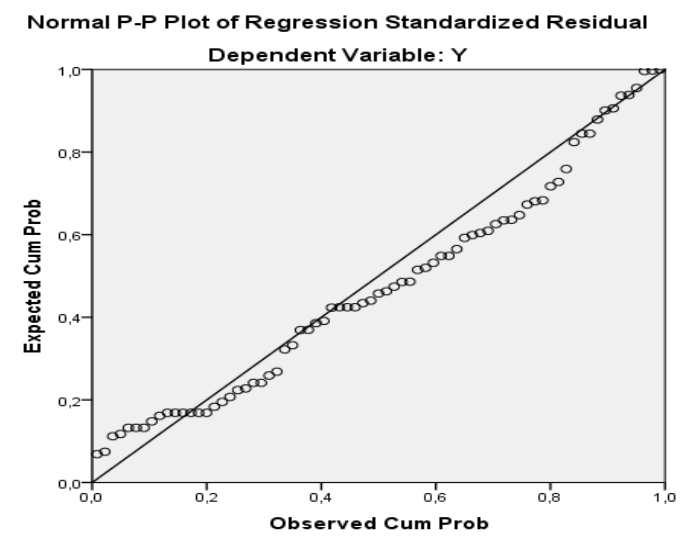

Gambar 6. Hasil Uji Normalitas Data

Sumber: Hasil olah data oleh peneliti

Uji asumsi selanjutnya adalah uji Multikolinearitas yaitu untuk mengidentifikasi hubungan korelasi antara variabel bebas dengan melihat nilai Pearson Correlation (r). Dikatakan tidak adanya multikolinearitas suatu hubungan variabel bebas jika nilai $r<0,6$

Tabel 1 Hasil Uji Multikolinearitas

\begin{tabular}{ccccc}
\hline \multicolumn{1}{c}{} & & Y & X1 & X2 \\
\hline Pearson Correlation & $\mathrm{Y}$ & 1,000 &, 464 &, 536 \\
& $\mathrm{X} 1$ &, 464 & 1,000 &, 398 \\
$\mathrm{X} 2$ &, 536 &, 398 & 1,000 \\
\hline
\end{tabular}

Sumber: Hasil olah data oleh peneliti

Dari data tabel dan melihat nilai Pearson Corellation dapat disimpulkan bahwa tidak adanya multikolinearitas di dalam model regresi pada penelitian ini karena nilai $r<0,6$. Uji asumsi berikutnya adalah uji Heteroskedastisitas, mengukur perbedaan variansi suatu bentuk regresi dan residual dari pengamatan satu ke pengamatan lainnya. Jika variansi dari residual satu pengamatan ke pengamatan lain tetap, maka disebut Homoskedastisitas dan jika berbeda disebut Heteroskedastisitas (Wibowo, 
2012). Deteksi heteroskedastisitas dapat dilakukan dengan metode scatter plot dengan memplotkan nilai ZPRED (nilai prediksi) dengan SRESID (nilai residual nya). Suatu model regresi apabila tidak terdapat heteroskedastisitas dengan melihat diagram pencar residual yang tidak membentuk pola tertentu. Diagram pencar residual dapat dilihat dari gambar di bawah ini.

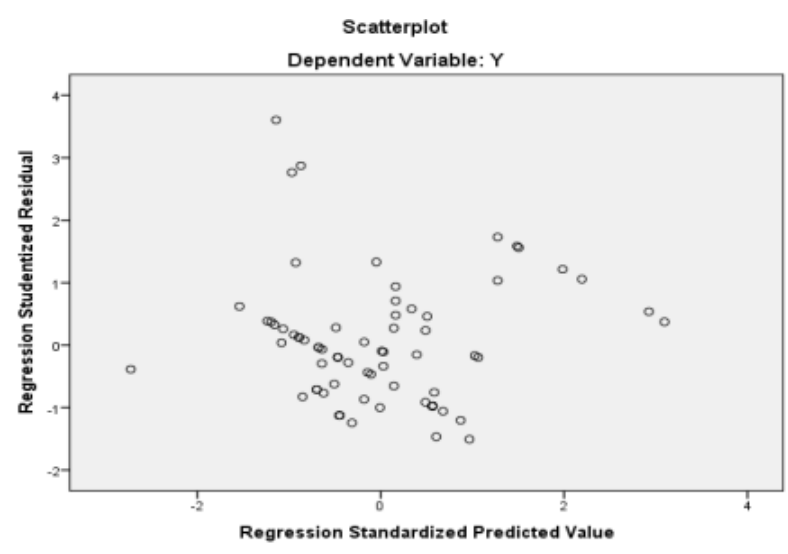

Gambar 7. Hasil Uji Heteroskedastisitas

Sumber: Hasil olah data oleh peneliti

Dari hasil gambar uji heteroskedastisitas diketahui tidak terdapat pola tertentu pada grafik, seperti mengumpul di tengah, menyempit kemudian melebar atau sebaliknya melebar kemudian menyempit, baik di atas maupun di bawah angka 0 maka dapat dinyatakan tidak terjadi heteroskedastisitas dan layak diterima kebenaran pengujian hipotesis penelitian ini secara ilmiah dengan menggunakan analisis regresi linier berganda untuk memprediksi Y berdasarkan masukan variabel independennya $(\mathrm{X})$.

a. Analisis Regresi Linier Berganda

Hasil perhitungan analisis regresi linier berganda sebagai berikut:

Tabel 2. Model Persamaan Regresi Berganda

\begin{tabular}{crrrrr}
\hline \multirow{2}{*}{ Model } & \multicolumn{2}{c}{$\begin{array}{c}\text { Unstandardized } \\
\text { Coefficients }\end{array}$} & $\begin{array}{c}\text { Standardized } \\
\text { Coefficients }\end{array}$ & \multirow{2}{*}{$\mathrm{t}$} & \multirow{2}{*}{ Sig. } \\
\cline { 2 - 4 } & \multicolumn{1}{c}{ B } & Std. Error & Beta & & \\
\hline (Constant) & 15,028 & 7,011 & & 2,144 & 0,036 \\
1 X1 & 0,250 & 0,087 & 0,298 & 2,865 & 0,005 \\
X2 & 0,313 & 0,078 & 0,418 & 4,015 & 0,000 \\
a. Dependent Variable: Y & & & & \\
\hline
\end{tabular}

Sumber: Hasil olah data primer oleh peneliti

Persamaan regresi linier berganda sebagai berikut: adalah $\hat{Y}=15,028+0,250 \mathrm{X}_{1}+0,313 \mathrm{X}_{2}$. Berdasarkan persamaan tersebut maka dapat diketahui bahwa konstanta 15,028 menunjukkan bahwa kinerja anggota Reskrim Polres Blitar Kota dalam pengamanan Pemilihan Gubernur Jawa Timur tahun 2018 jika tanpa memperhitungkan kompetensi dan motivasinya memiliki nilai sebesar 15,028 satuan, jika kompetensi $\left(\mathrm{X}_{1}\right)$ naik satu satuan, maka kinerja (Y) akan meningkat sebesar 0,250 satuan, dengan anggapan variabel lain konstan. Bila variabel motivasi $\left(\mathrm{X}_{2}\right)$ naik satu satuan, maka kinerja $(\mathrm{Y})$ akan meningkat sebesar 0,313 satuan, dengan anggapan variabel lain konstan. Menurut penjelasan tersebut 
maka dapat diketahui bahwa kompetensi dan motivasi memberikan pengaruh positif terhadap kinerja anggota Reskrim Polres Blitar Kota dalam pengamanan Pemilihan Gubernur Jawa Timur tahun 2018.

Temuan dari persamaan regresi linier berganda di atas didukung dengan temuan hasil uji $t$ sebagaimana pada tabel dibawah ini :

Tabel 3. Hasil Uji t

\begin{tabular}{cccc}
\hline \multicolumn{2}{c}{ Model } & $\mathrm{t}$ & Sig. \\
\hline \multirow{2}{*}{$\mathrm{X}_{1}$} & $($ constant $)$ & 2,144 & 0,036 \\
$\mathrm{X}_{2}$ & & 2,865 & 0,005 \\
& & 4,015 & 0,000 \\
\hline
\end{tabular}

Sumber: hasil olah data primer oleh peneliti

Dari hasil tabel 3 uji t, menunjukkan bahwa hipotesis ha ${ }_{1}$ diterima. Penerimaan hipotesis ini dapat diamati pada nilai $t_{\text {hitung }}$ kompetensi anggota $\left(\mathrm{X}_{1}\right)$ memiliki nilai 2,865 lebih besar dibandingkan dengan $t_{\text {tabel, }} \mathrm{n}=73$ yaitu 1,99300. Dan membandingkan antara nilai signifikansi kompetensi $\left(\mathrm{X}_{1}\right)=0,005$ lebih kecil jika dibandingkan dengan nilai taraf nyata sebesar 0,05. Maka hasil perhitungan ini menunjukkan secara parsial kompetensi berpengaruh signifikan terhadap kinerja.

Untuk hipotesis ha $\mathrm{a}_{2}$ diterima, dengan melihat nilai thitung motivasi $\left(\mathrm{X}_{2}\right)$ memiliki nilai 4,015 lebih besar dibandingkan dengan $t_{\text {tabel, }} \mathrm{n}=73$ yaitu 1,99300. Dan membandingkan antara nilai signifikansi motivasi $\left(\mathrm{X}_{2}\right)=0,000$ yang lebih kecil jika dibandingkan dengan nilai taraf nyata yaitu 0,05 . Maka hasil perhitungan ini menunjukkan bahwa secara parsial motivasi berpengaruh signifikan terhadap kinerja.

Tabel 4 Hasil Perhitungan Uj F

\begin{tabular}{lrrrrc}
\hline Model & Sum of Squares & $d f$ & Mean Square & $F$ & Sig. \\
\hline Regression & 769,563 & 2 & 384,781 & $\mathbf{1 9 , 9 0 1}$ & $\mathbf{, 0 0 0}^{\mathbf{b}}$ \\
1 Residual & 1353,451 & 70 & 19,335 & & \\
Total & 2123,014 & 72 & & & \\
a. Dependent Variable: $Y$ & & & \\
b. Predictors: (Constant), X2, X1 \\
\hline \multicolumn{5}{c}{ Sumber: Hasil olah data primer oleh peneliti }
\end{tabular}

Dari hasil per hitungan pada tabel 4 bahwa nilai Sig sebesar 0,000 dimana nilai tersebut lebih kecil dari $\alpha=0,05$ sehingga terdapat pengaruh kompetensi dan motivasi terhadap kinerja. Hasil uji $F_{\text {hitung }}$ $=19,901$ dengan nilai Sig $=0,000$. Diketahui $\mathrm{F}_{\text {tabel }}$ dengan tingkat keyakinan 95\%, $\alpha=5 \%$, df $(2,70)$ dengan pengertian $\mathrm{df}_{1}=($ banyaknya variabel $\mathrm{X}$ dan $\mathrm{Y})-1$ atau $\mathrm{df}_{1}=3-1=2$, dan $\mathrm{df}_{2}=(\mathrm{n}-\mathrm{k})$ atau $\mathrm{df}_{2}$ $=73-3=70$ ( $\mathrm{n}$ adalah banyaknya responden dan $\mathrm{k}$ adalah banyaknya variabel dalam $\mathrm{X}$ dan $\mathrm{Y}$ ), sehingga $F_{\text {tabel }}=3,125$. Berdasarkan ketentuan $F_{\text {hitung }}>F_{\text {tabel }}$ dan nilai signifikansi hasil uji $F$ yang lebih kecil daripada nilai taraf nyata, maka hipotesis $\mathrm{h}_{\mathrm{a} 3}$ atau hipotesis adanya pengaruh kompetensi dan motivasi secara simultan terhadap kinerja diterima.

Selanjutnya menggunakan perhitungan koefisien determinasi untuk mengukur seberapa besar pengaruh dari variabel bebas terhadap variabel terikat. Dalam regresi linier berganda digunakan untuk mengetahui prosentase sumbangan pengaruh variabel independen (kompetensi dan motivasi) secara serempak terhadap variabel dependen (kinerja). 
Earlyanti, N.I. \& Ardiansyah, D. (2021). Pengaruh Kompetensi dan Motivasi terhadap ....

\begin{tabular}{|c|c|c|c|c|}
\hline Model & $\mathrm{R}$ & R Square & Adjusted R Square & Std. Error of the Estimate \\
\hline 1 & $0,602^{\mathrm{a}}$ & 0,362 & 0,344 & 4,39716 \\
\hline $\begin{array}{ll}\text { a. } & \operatorname{Pr} \\
\text { b. } & \mathrm{D}\end{array}$ & $\begin{array}{l}\text { ictors: (C } \\
\text { endent V }\end{array}$ & $\begin{array}{l}\text { nstant), } X_{2}, X \\
\text { iabel: Y }\end{array}$ & & \\
\hline
\end{tabular}

Sumber: Hasil olah data primer oleh peneliti

Dari data tabel 5, nilai Adjusted R Square sebesar 0,344 atau 34,4\%, variabel kompetensi dan motivasi dapat menjelaskan pengaruhnya terhadap kinerja, sisanya $65,6 \%$ dipengaruhi oleh variabel lain di luar dari variabel yang diteliti, misalnya gaya kepemimpinan, budaya organisasi, dan komitmen.

\section{Pembahasan}

\section{Pengaruh Kompetensi terhadap Kinerja}

Dari hasil uji $\mathrm{t}$ untuk melihat pengaruh kompetensi terhadap kinerja anggota secara parsial diperoleh $\mathrm{t}_{\text {hitung }} 2,865>\mathrm{t}_{\text {tabel }} 1,993$ dan signifikansi 0,005 $<0,05$ berarti kompetensi berpengaruh positif dan signifikan terhadap kinerja anggota. Kompetensi adalah karakteristik perilaku yang dimiliki seseorang dalam pekerjaannya yang dapat menunjukkan perbedaan antara mereka yang berkinerja tinggi dan rendah. Kompetensi seseorang akan menunjukkan pekerjaan yang pernah dilakukan dan peluang untuk melakukan pekerjaan lebih baik (Safwan dkk, 2014). Sejalan dengan hasil penelitian Osei \& Ackah (2015) bahwa seseorang yang memiliki kompetensi yang tinggi akan memiliki kinerja yang tinggi. Kompetensi yang tinggi akan mampu memberikan kinerja yang lebih memuaskan bagi organisasi, sebaliknya seseorang yang memiliki kompetensi rendah akan memberikan kinerja yang cenderung kurang memuaskan bagi organisasi. Hal ini terjadi karena seseorang yang memiliki kompetensi tinggi akan dapat memperdalam dan memperluas jangkauan kerjanya, sehingga kinerja yang ditargetkan oleh organisasi akan mudah tercapai. Kompetensi yang dimiliki anggota Reskrim Polres Blitar Kota merupakan input untuk menciptakan kinerja (outcome) dalam rangka pengamanan pemilihan Gubernur Jawa Timur tahun 2018.

Dharma (2018) menyatakan bahwa kompetensi adalah hal yang dibawa seseorang ke dalam pekerjaannya dalam bentuk, jenis, dan perilaku yang berbeda-beda. Hal ini mengacu pada atribut yang membangun kompetensi individu, seperti pengetahuan, keahlian dan kepiawaian. Apabila atribut tersebut memiliki kualitas yang tinggi maka akan menghasilkan kinerja yang tinggi, begitu juga sebaliknya. Seseorang yang memiliki kompetensi tinggi akan mampu mengambil resiko kerja, menyikapi dengan bijaksana, tanggung jawab dalam mempertahankan produktivitas kerjanya. Peningkatan kompetensi akan berdampak pada peningkatan kinerja (Kolibáčová, 2014). Indikatorindikator pembangun kompetensi yang memiliki nilai tinggi akan berpengaruh terhadap kinerja (Sujiati, 2017). Hal ini akan terlihat pada perbedaan antara mereka yang memiliki kinerja tinggi dan rendah, dengan melihat kompetensi yang dimiliki anggota dalam menciptakan kondisi yang kondusif saat melakukan pengamanan. 


\section{Pengaruh Motivasi terhadap Kinerja}

Hasil uji $t$ untuk melihat pengaruh motivasi terhadap kinerja anggota diperoleh $t_{\text {hitung }} 4,015>$ $t_{\text {tabel }} 1,993$ dan signifikansi $0,000<0,05$ berarti motivasi berpengaruh positif dan signifikan terhadap kinerja anggota. Hunsaker (2002) dalam Usman (2013) menyatakan bahwa keberadaan motivasi di dalam diri seseorang akan mampu menjadi faktor pendorong untuk bekerja dan memperkuat komitmen, sehingga akan meningkatkan produktivitas kerja. Hal ini karena motivasi dapat memaksa seseorang untuk berupaya dan bekerja lebih keras mencapai hasil kerja yang optimal. Motivasi sebagai proses yang dapat menjelaskan intensitas, arah, dan ketekunan seorang individu untuk mencapai tujuan (Robbins and Judje, 2009).

Hasil penelitian Pamela Akinyi Omollo (2015) menyatakan motivasi memiliki pengaruh positif dan signifikan terhadap kinerja. Motivasi yang ada dalam diri seseorang akan mampu memberikan dorongan yang kuat sehingga seseorang dapat lebih intens, lebih giat, dan lebih keras dalam berusaha agar tujuannya tercapai. Seseorang yang memiliki motivasi kuat akan mampu mendorong produktifitas kerja, sehingga kinerja atau prestasi kerjanya meningkat. Mar'at dalam Warsito (2008) menjelaskan bahwa motivasi menjadi faktor pendorong ketika bekerja, salah satunya disebabkan oleh adanya berbagai kebutuhan yang harus dipenuhi. Seseorang yang memiliki motivasi tinggi akan bekerja lebih keras agar kebutuhannya tercapai secara optimal, efektif dan efisien. Semakin tinggi motivasi maka kinerja akan semakin baik, begitu pun sebaliknya. Hal ini ditegaskan dari hasil penelitian Cherian \& Jacob (2013), motivasi adalah sebagai determinan utama dari kinerja.

\section{Pengaruh Kompetensi dan Motivasi terhadap Kinerja}

Secara simultan pengaruh kompetensi dan motivasi terhadap kinerja dapat dilihat dari hasil uji F; $F_{\text {hitung }} 19,901>\mathrm{F}_{\text {tabel }} 3,125$ dan nilai signifikansi $0,000<0,05$ berarti kompetensi dan motivasi berpengaruh terhadap kinerja secara simultan. Amstrong dan Baron (1998) dalam Wibowo (2017) mengemukakan kompetensi dan motivasi merupakan bagian dari personal factors. Kompetensi dan motivasi merupakan faktor yang mempengaruhi dalam pelaksanaan kinerja. Kinerja merupakan fungsi dari keinginan (motivasi) untuk melakukan pekerjaan, keterampilan dan pemahaman (kompetensi) yang diperlukan dalam mengerjakan dan menyelesaikan tugas. Adanya hubungan kompetensi dan motivasi sebagai personal factors akan memiliki pengaruh terhadap kinerja yang dihasilkan. Jika kompetensi dan motivasi tinggi maka kinerja yang dihasilkan tinggi dan sebaliknya jika kompetensi dan motivasi rendah maka kinerja yang dihasilkan rendah.

Hal ini diperkuat dari perolehan nilai adjusted $R$ Square pada uji koefisien determinasi sebesar 0,344 yang menjelaskan kompetensi dan motivasi memiliki pengaruh terhadap kinerja sebesar 34,4\% dan sisanya sebesar 65,6\% dipengaruhi oleh faktor lain, seperti iklim kerja di organisasi, beban kerja yang diterima anggota, ketatnya pengawasan yang dilakukan oleh pimpinan terkait pelaksanaan kerja, aspek kedisiplinan anggota dalam bekerja, maupun dari variabel lainnya 


\section{KESIMPULAN DAN SARAN}

Dapat disimpulkan terdapat pengaruh antara kompetensi dan motivasi terhadap kinerja, baik secara parsial maupun simultan. Kemampuan anggota dalam melakukan pengamanan untuk menciptakan kondisi yang kondusif didorong oleh motivasi positif pada diri anggota akan memberikan kontribusi pada kinerja. Kemampuan anggota dalam memilih dan menerapkan sistem pengamanan yang tepat membutuhkan motivasi dari diri anggota untuk dapat menghasilkan kinerja yang baik pada hasil tugas yang dilaksanakan.

Saran untuk langkah berikutnya dapat dilakukan pendidikan dan pelatihan secara berkesinambungan untuk membangun kompetensi anggota dan menciptakan motivasi positif dalam diri anggota maupun dalam tim kerja, sehingga kinerja yang terbangun akan bersinergi dengan semua aspek sebagai satu kesatuan yang utuh. 


\section{DAFTAR PUSTAKA}

Amiati, Ita. dan Supriyanto. (2012). Pengaruh Motivasi Kerja terhadap Kinerja Karyawan Bagian Marketing Bank Ayariah (Studi Kasus Pada Karyawan PT.BPRS Pemerintah Kota Bekasi). Maslahah. Vo.1 No.1. p.1-9.

Anjani, Ayu. (2019). Pengaruh Kompetensi dan Motivasi Terhadap Kinerja Karyawan. Jurnal Inspirasi Bisnis dan Manajemen, e-ISSN 2579-9401. Vol.3 No.1. p.1-10.

Asshidiqie, Jimly. (2013). Menegakkan Etika Penyelenggaraan Pemilu. Jakarta : Rajawali Pers.

Cherian, J. dan Jacob, J. (2013). Impact of Self Efficacy on Motivation and Performance of Employees. International Journal of Business and Management. Vol.8. No.14. p.80-88.

Dahniel, Rycko Amelza dan Surya Dharma. (2013). Manajemen Sumber Daya Manusia Di Sektor Jasa Tenaga Sekuriti. Yogyakarta: Pustaka Pelajar.

Dahniel, Rycko Amelza dan Surya Dharma. (2016). Perilaku Organisasi Kepolisian. Yogyakarta: Pustaka Pelajar.

Dharma, Surya. (2018). Manajemen Kinerja Falsafah, Teori dan Penerapannya. Yogyakarta : Pustaka Pelajar.

Edison, E., Anwar, Y., dan Komariyah, I. (2017). Manajemen Sumber Daya Manusia. Bandung: Alfabeta.

Ghozali. Imam (2005). Aplikasi analisis multivariate dengan program SPSS. Semarang: Badan Penerbit Universitas Diponegoro.

Handoko, T. Hani. (2005). Manajemen Personalia dan Sumber Daya Manusia. Edisi 2. Yogyakarta: Balai Penerbit Fakultas Ekonomi.

Kolibáčová, G. (2014). The Relationship Between Competency And Performance. Jurnal Acta Universitatis Agriculturae et Silviculturae Mendelianae Brunensis. Vol.62 No.6. p.1315-1327.

Mangkunegara, A. A. P. (2013). Manajemen Sumber Daya Manusia Perusahaan. Bandung: Remaja Rosdakarya.

Nazriyah, R. (2013). Dinamika Pemilihan Gubernur Jawa Timur. Jurnal Hukum Ius Quia Iustum. Vol. 20. No. 4., p. 641-665. 
Nitibaskara, Tb. Ronny Rachman. (2018). Persiapan Polri Menghadapi Pilkada 2018 Dan Pilpres 2019. Jurnal Ilmu Kepolisian. Vol.12. No. 1., p. 18-23.

Omollo, Pamela Akiyinyi. (2015). Effect Of Motivation On Employee Performance Of Commercial Bank In Kenya : A Case Study of Kenya Commercial Bank In Migori County. Vol. 5 No. 2. p. 87103.

Osei, A. J., dan Ackah, O. (2015). Employee's Competency And Organizational Performance In The Pharmaceutical Industry. International Journal of Economic, Commerce and Management United Kingdom. Vol.3. No.3. p.1-9.

Prasetyo, Bambang dan Lina Miftahul Jannah. (2011). Metode Penelitian Kuantitatif: Teori dan Aplikasi. Jakarta: PT. RajaGrafindo Persada.

Robbins dan Judge. (2009). Organizational Behavior. Edisi 13. New Jersey: Pearson Education Inc.

Safwan. Nadirsyah. dan Syukriy Abdullah. (2014). Pengaruh Kompetensi dan Motivasi terhadap Kinerja Pengelolaan Keuangan Daerah pada Pemerintahan Daerah Kabupaten Pidie Jaya. Jurnal Akuntansi Pascasarjana Universitas Syiah Kuala. Vol. 3. No. 1. p. 133-139.

Simamora, Henry. (2004). Manajemen Sumber Daya Manusia. Yogyakarta: STIE YKPN.

Spencer, Lyle dan Singe M. Spancer. (2003). Competence at Work Models for Superior Performance. Canada: John Wiley \& Son.

Sriwidodo., Untung Haryanto dan Budhi Haryanto. (2010). Pengaruh Kompetensi, Motivasi, Komunikasi dan Kesejahteraan Terhadap Kinerja Pegawai Dinas Pendidikan. Jurnal Manajemen Sumber Daya Manusia. Vo.4 No.1. p. 47-57.

Sugiyono. (2015). Metode Penelitian Kuantitatif dan Kualitatif. Bandung. Alfabeta

Sujiati. (2017). The Effect Of Motivation And Competence On Employee Performance In Satellite Technology Center - National Institute Aeronautics And Space. Journal of Applied Management. Vol. 15. No. 2. p. 229-237.

Uno, Hamzah. (2009). Teori Motivasi dan Pengukurannya (Analisis di Bidang Pendidikan). Jakarta: Bumi Aksara.

Usman, Husaini. (2013). Manajemen: Teori, Praktik, dan Riset Pendidikan. (Edisi 4). Jakarta: PT. Bumi Aksara. 
Warsito, Bambang. (2008). Manajemen Sumber Daya Manusia. Malang: Surya Pena Gemilang.

Wibowo. (2007). Manajemen Kinerja Edisi Ketiga. Jakarta: Rajawali Pers.

Wibowo. (2014). Budaya Organisasi: Sebuah Kebutuhan untuk Meningkatkan Kinerja Jangka Panjang. (Edisi 1). Jakarta: PT. RajaGrafindo Persada.

Wibowo. (2017). Manajemen Kinerja. Jakarta: PT. Raja Grafindo Persada

Yuningsih, Erni. dan Ardianti. (2019). Pengaruh Kompetensi dan Motivasi Terhadap Kinerja Pegawai Pada PT XXX. Jurnal Visionida. Vo.5 No.1. p. 32-45. 